\title{
Rooting in Leaf Petioles of Arachis for Cytological Analysis
}

\author{
Alessandra P. Fávero ${ }^{1,2, *}$, Silvia M. Cuco ${ }^{2}$, Margarida L. R. de Aguiar-Perecin ${ }^{2}$, \\ José F. M. Valls ${ }^{1}$ and Natal A. Vello ${ }^{2}$ \\ ${ }^{1}$ Embrapa Genetic Resources and Biotechnology, SAIN Parque Estação Biológica, CP 02372, \\ 70.770-900, Brasília-DF, Brazil \\ ${ }^{2}$ Department of Genetics, Faculty of Agriculture "Luiz de Queiroz" University of São Paulo, \\ C.P. $83,13400-970$, Piracicaba, SP, Brazil
}

Received March 15, 2004; accepted April 3, 2004

\begin{abstract}
Summary Method of rooting in petioles was developed for leaves of Arachis plants. The objective was the development of methodology that allows the chromosome number determination for evaluation of the ploidy level in colchicine-treated branches. In order to obtain a high frequency of metaphases and chromosomes with clear morphology, roots were pretreated with 8-hydroxyquinoline combined to cycloheximide for $2 \mathrm{~h}$. Root tips were stained using Feulgen dye for chromosome analysis. This method can be applied also for cytological studies of materials in which seeds are not available or cutting is not feasible.
\end{abstract}

Key words Arachis, Chromosomes, Rooting, Polyploidy, Cytology.

Wild Arachis species have been extensively studied due to their potential use in groundnut (Arachis hypogaea L.) breeding and as forage and ornamental crops. Several wild species have shown interesting characteristics for groundnut breeding programs, mainly involving biotic resistance factors (Gardner and Stalker 1983, Stalker and Moss 1987, Stalker 1989, Starr et al. 1990, Singh et al. 1996, Simpson and Starr 2001).

Arachis hypogaea is an allotetraploid (AABB) (Singh et al. 1991, Krapovickas and Gregory 1994), with $2 n=40$. Most of the wild Arachis species are diploid with $2 n=20$ (Fernández and Krapovickas 1994). In Arachis section, several wild species have A genome, which can be cytologically characterized and differentiated from other species by the presence of a pair of chromosomes much smaller than the others, with different staining characteristics (Husted 1933, 1936). It was believed that there was another genome in groundnut, which did not have the pair "A", and which could be observed with a secondary constriction and an associated satellite in one chromosome. These chromosomes were called "chromosomes B" in classical works (Husted 1936). Presently, however, it is known that all species cytologically analyzed in the genus Arachis have a chromosome pair (and eventually two) with satellites, called chromosome SAT (Fernández and Krapovickas 1994). Thus the presence of a SAT chromosome does not guarantee the exact classification as a representing of the B genome of the groundnut. Consequently, the general concept of B genome species is more restricted, requiring being diploid and belonging to the Arachis section, sharing the same B genome of the cultivated groundnut and not having the pair "A". Thus there is no guarantee that all species of Arachis Section that do not have "A" pair shares the same B genome of the cultivated groundnut. In this paper, such species are referred to as presenting a "non-A" genome. This includes those diploids species belonging to the Arachis section, but not having the "A" pair and not necessarily sharing the same B genome of the cultivated peanut.

The objective of this paper was to present a method to obtain rooting for cytological analysis and to adapt a root pre-treatment and chromosome preparation protocol for analysis of somatic chromosomes of Arachis.

\footnotetext{
* Corresponding author, e-mail: favero@cenargen.embrapa.br
} 
Materials and methods

Ten accessions of wild species with A genome $(2 x=20)$ were crossed to five accessions of wild species with "non-A" genome $(2 x=20)$ generating sterile $\mathrm{F}_{1}$ individuals, which were treated with colchicine for chromosome duplication.

Some techniques were considered to obtain a preliminary evaluation of the ploidy level of the $\mathrm{F}_{1}$ 's individuals cuttings treated with colchicine. Data referring to the viability of pollen, size and number of stomata for each area unit can indicate parameters of different ploidy levels among the genotypes (Barbosa and Vieira 1997, Tallury and Copeland 2002). However, most of the cuttings did not produce flowers that could be used to test pollen viability, besides the fact that tetraploidized plants tend to retard the period of offspring when compared to diploid hybrids (C. E. Simpson, personnal communication). A technique for determining stomata number and size has not been conclusive. Thus, to verify the ploidy level, a technique for direct chromosomes counting from colchicinetreated branches was tried.

The experiment was carried out at Piracicaba-SP, Brazil $\left(22^{\circ} 42^{\prime} \mathrm{S}\right.$ and $\left.47^{\circ} 38^{\prime} \mathrm{W}\right)$ under greenhouse condition, with the temperature varying from 21 to $38^{\circ} \mathrm{C}$. New totally expanded leaves from colchicine-treated cuttings had their petioles cut and sprayed with the rooting hormone indol-butiric acid (IBA) in their extremities and immediately put in plastic cups with vegetable subtract. Cups were put on a tray and covered with a transparent plastic bag for maintenance of humidity. Seventeen interspecific hybrids combinations were analyzed (Table 1).

Methodologies of root treatment and cytological preparations were adapted from AguiarPerecin and Vosa (1985) and Silvarolla and Aguiar-Perecin (1994). Inhibitor of the mitotic spindle fibers (8-hydroxyquinoline) and the protein synthesis inhibitor (cycloheximide) were used for optimizing chromosome preparations having spread chromosomes, clear morphology and high metaphase frequency. Roots with approximately $1 \mathrm{~cm}$ were collected, immediately treated with a solution of $300 \mathrm{ppm} 8$-hydroxyquinoline and 3.125 or $6.25 \mathrm{ppm}$ cycloheximide during $1.5 \mathrm{~h}$ and $2 \mathrm{~h}$ respectively, and fixed with ethanol/acetic acid $(3: 1)$. Roots were stained according to Feulgen methodology, hydrolyzed in $1 \mathrm{~N} \mathrm{HCI}$ for $9 \mathrm{~min}$ at $60^{\circ} \mathrm{C}$ and stained with Schiff's reagent for $45 \mathrm{~min}$,

Table 1. Hybrids, species and respective accessions used as male and female parents and results obtained with cytological analysis (major ploidy level found)

\begin{tabular}{|c|c|c|c|c|c|c|c|}
\hline \multicolumn{3}{|c|}{ Female Parents (A genome) } & \multicolumn{4}{|c|}{ Male Parents (B genome) } & \multirow{2}{*}{$\begin{array}{l}\text { Ploidy } \\
(x=10)\end{array}$} \\
\hline Species & Accession & BRA & & Species & Accession & BRA & \\
\hline \multirow[t]{4}{*}{ A. batizocoi } & K 9484 & 013315 & $\times$ & A. cardenasii & GKP 10017 & 013404 & $4 x$ \\
\hline & & & $\times$ & A. duranensis & VNvEv 14167 & 036200 & $4 x$ \\
\hline & & & $\times$ & A. helodes & VSGr 6325 & 012505 & $2 x$ \\
\hline & & & $\times$ & A. kempff-mercadoi & V 13250 & 030643 & $4 x$ \\
\hline \multirow{3}{*}{ A. magna } & VSPmSv 13751 & 033812 & $\times$ & A. cardenasii & GKP 10017 & 013404 & $4 x$ \\
\hline & & & $\times$ & A. stenosperma & Lm 3 & 036005 & $4 x$ \\
\hline & & & $\times$ & A. linearifolia & VPoBi 9401 & 022608 & $2 x$ \\
\hline \multirow[t]{5}{*}{ A. aff. magna } & VSGr 6389 & 012696 & $\times$ & A. duranensis & VNvEv 14167 & 036200 & $2 x$ \\
\hline & & & $\times$ & A. stenosperma & VGaRoSv 12488 & 030651 & $4 x$ \\
\hline & & & $\times$ & A. villosa & VGoMrOv 12812 & 030813 & $4 x$ \\
\hline & & & $\times$ & A. kuhlmannii & VSPmSv 13721 & 033723 & $4 x$ \\
\hline & & & $\times$ & A. linearifolia & VPoBi 9401 & 022608 & $4 x$ \\
\hline \multirow[t]{3}{*}{ A. hoehnei } & KG 30006 & 036226 & $\times$ & A. simpsonii & VSPmSv 13710 & 033685 & $2 x$ \\
\hline & & & $\times$ & A. helodes & VSGr 6325 & 012505 & $4 x$ \\
\hline & & & $\times$ & A. cardenasii & GKP 10017 & 013404 & $4 x$ \\
\hline \multirow[t]{2}{*}{ A. ipaensis } & KGPScS 30076 & 036234 & $\times$ & A. duranensis & VNvEv 14167 & 036200 & $4 x$ \\
\hline & & & $\times$ & A. villosa & VGoMrOv 12812 & 030813 & $4 x$ \\
\hline
\end{tabular}


in the dark. After the reaction, an enzymatic digestion with a solution containing $2 \%$ cellulase and $3 \%$ pectinase (both from Aspergillus niger) for $10 \mathrm{~min}$ at $37^{\circ} \mathrm{C}$, succeeded by a washing in citrate buffer ( $4 \mathrm{mM}$ citric acid $+6 \mathrm{mM}$ trisodium citrate) has proceed. For chromosome preparations, the stained meristematic regions were squashed on to a drop of $1 \%$ aceto-carmine with a slight compression for chromosome spreading. After selection, coverslips were removed in $45 \%$ acetic acid and mounted with Canadian balsam. Photomicrographs of the chromosomes were obtained with a Zeiss photomicroscope, using a Kodak Technical Pan (ISO 25) film.

\section{Results and discussion}

The use of detached leaves showed high efficiency for obtaining rooting in petioles. The rooting occurred from one week up to $20 \mathrm{~d}$ after the isolation of the leaf. The period of rooting varied, apparently due to the size and age of the leaf. Younger and larger leaves required shorter time for rooting. It is believed that the environment temperature between 21 and $38^{\circ} \mathrm{C}$ also helped to obtain roots. This rooting technique possibly could be used with other species of plants, like soybean (Glycine max), in which the rooting of petioles has also been tested with success by the first author (data not shown). The present technique can also be adapted in case of species with non-availability of seeds and/or impossibility of cutting. The quantity and quality of the roots produced were compatible with the application of cytological techniques. Fig. 1 shows a petiole rooted from a leaf of a hybrid between Arachis batizocoi and Arachis cardenasii.

The use of a combination of $300 \mathrm{ppm} 8$-hydroxyquinoline and $6.25 \mathrm{ppm}$ cycloheximide for $2 \mathrm{~h}$ was the most efficient treatment and allowed obtaining of cytological preparations with a high rate of metaphases and prometaphases, with an adequate condensation of chromosome, that made it possible their counting and identification in the several hybrid combinations analyzed. Other substances have been already used successfully in the observation of mitotic chromosomes in species of Arachis, like paradiclorobenzene (Stalker et al. 1991, Stalker and Dalmacio 1981), bromonaphtalene (Peñaloza 1995, Fávero 1999), pure 8-hydroxyquinoline (Fernández and Krapovickas 1994). The satisfactory spreading of chromosomes in the cells can be due to the use of cellulase and pectinase, and to the heating of the slide before the superposition of the coverslips. Various roots of each plant were evaluated. Somatic chromosomes of diploid hybrid $(2 x=20) \mathrm{K} 9484$ (A. batizocoi) $\times \mathrm{V} 6325$ (A. helodes) can be visualized in Fig. 2a. Cell of a hybrid with successful duplication of the chromosome number $(4 x=40)$, resulting from the crossing $\mathrm{V}$ 6389 (A. aff. magna) $\times \mathrm{V} 12812$ (A. villosa) is shown in Fig. 2b. It is important to report the presence of a heteromorphic pair of chromosomes, indicated by arrows in Fig. 2. The presence of only one chromosome "A" was observed, in diploid hybrid individuals, once the crossing always involved accessions with

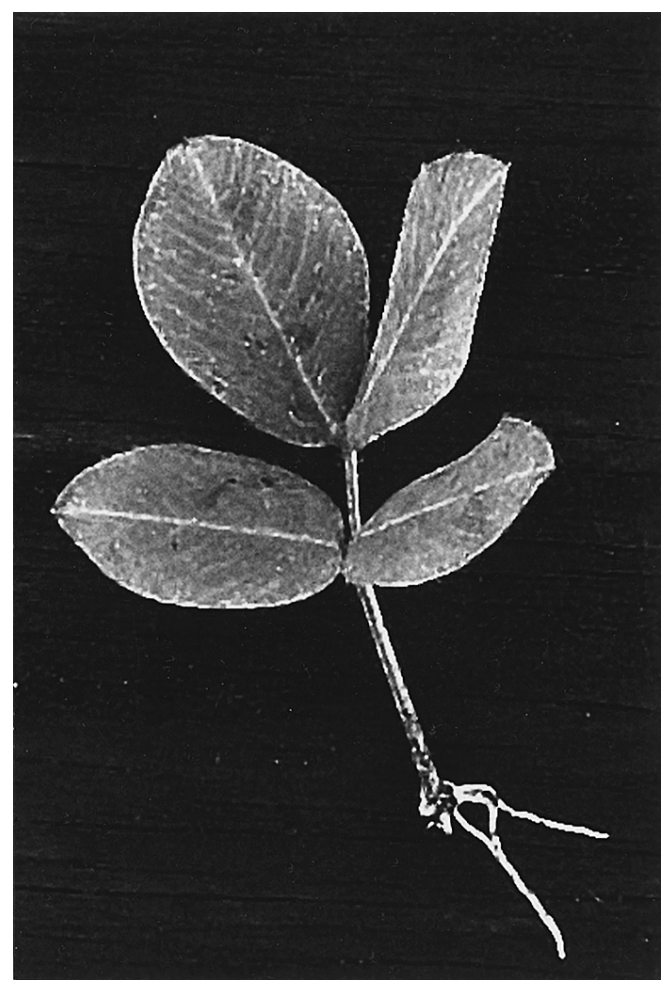

Fig. 1. Rooting leaf of hybrid between Arachis batizocoi (K 9484) and Arachis cardenasii (GKP 10017). 


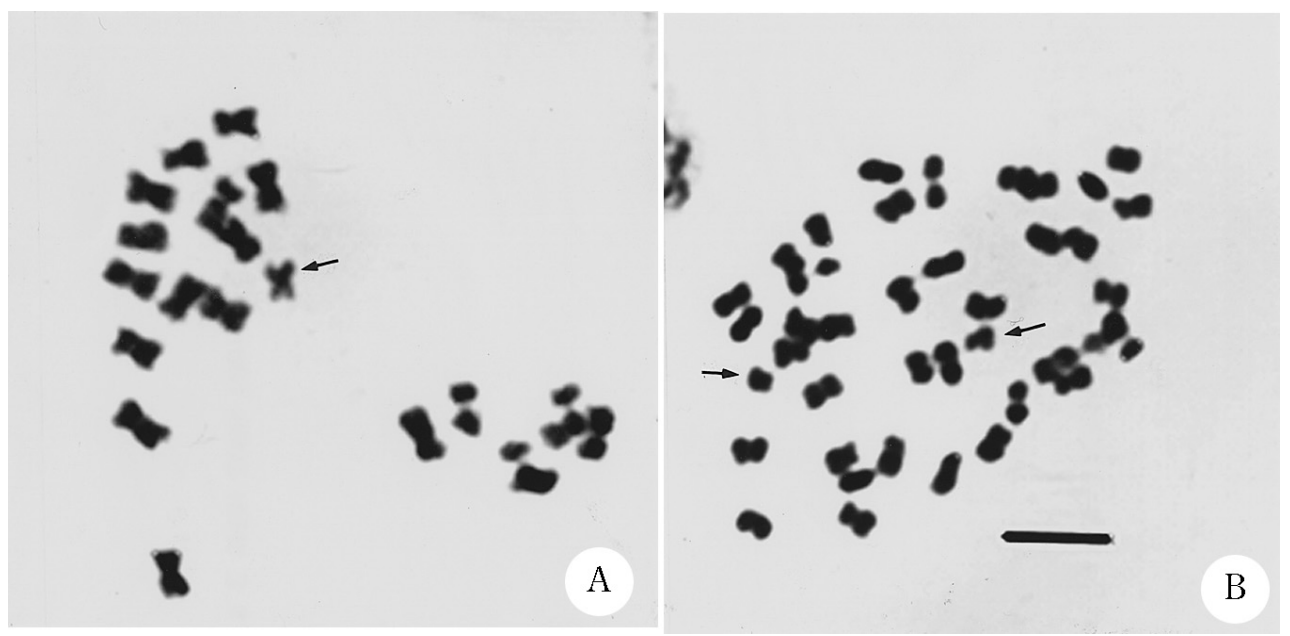

Fig. 2. A) Somatic chromosomes of diploid hybrid $(2 n=2 x=20)$ between $\mathrm{K} 9484($ A. batizocoi $) \times$ V 6325 (A. helodes), B) Tetraploid hybrid $(2 n=4 x=40)$ between V $6389($ A. gregoryi $) \times \mathrm{V} 12812$ (A. villosa). Black arrows show "A" chromosomes. Bar $=5 \mu \mathrm{m}$.

"A" and "non-A" genomes. In tetraploid individuals duplicated with colchicine a pair of "A" chromosomes was observed, indicating the allotetraploid structure of the individual.

This methodology allowed to recognize the polyploid and the non-polyploid hybrids, as well as counting and clear observation of chromosome morphology. Root pretreatment with combination of hydroxyquinoline and cycloheximide has been successfully used in cytological analysis of several species of plants, such as sugar cane (Silvarolla and Aguiar-Perecin 1994), corn (Bertão and Aguiar-Perecin 2002), Crotalaria sp. and Passiflora sp. (Cuco et al. in press).

Arachis has several wild species with characteristics of low prolificity, and consequently, a small number of individuals in the germplasm banks. Therefore, the cytogenetic characterization through mitotic analysis is much more difficult. The present technique of rooting leaves and the new protocol for root pretreatment may be interesting for species that have the capability of rooting in their petioles.

Procedures described in this paper were applied successfully for the discrimination of artificial polyploid hybrids produced with colchicine treatment, with the purpose of introgression of genes for resistance to Cercosporidium personatum, Cercospora arachidicola and Puccinia arachidis existing in wild species to the cultivated peanut.

\section{Acknowledments}

A.P.F. and N.A.V. thank the Fundação de Apoio à Pesquisa do Estado de São Paulo (FAPESP) for grant and financial assistance.

\section{References}

Aguiar-Perecin, M. L. R. and Vosa, C. 1985. C-banding in maize. II. Identification of somatic chromosomes. Heredity 54: $37-42$.

Barbosa, L. V. and Vieira, M. L. C. 1997. Meiotic behavior of passion fruit somatic hybrids, Passiflora edulis f. flavicarpa Degener plus P. amethystina Mikan. Euphytica 98: 121-127.

Bertão, M. R. and Aguiar-Perecin, M. L. R. 2002. Maize somatic chromosome preparation: pretreatments and genotypes for obtention of high index of metaphase accumulation. Caryologia 55: 115-199.

Cuco, S. M., Mondin, M., Vieira, M. L. C. and Aguiar-Perecin, M. L. R. Técnicas para a obtenção de preparações 
citológicas com alta freqüência de metáfases em plantas: Passiflora (Passifloraceae) e Crotalaria (Leguminosae). (In press).

Fávero, A. F. 1999. Caracterização morfológica, citogenética e molecular de acessos de germoplasma da espécie Arachis kuhlmannii Krapov. \& W. C. Gregory (Secção Arachis). MSc Thesis, UNESP, Botucatu-SP, Brazil.

Fernández, A. and Krapovickas, A. 1994. Cromosomas y evolución en Arachis (Leguminosae). Bonplandia 8: 187-220.

Gardner, M. E. B. and Stalker, H. T. 1983. Cytology and leafspot resistance of section Arachis amphidiploids and their hybrids with Arachis hypogaea. Crop Science 23: 1069-1074.

Husted, L. 1933. Cytological studies of the peanut Arachis. 1. Chromosome number and morphology. Cytologia 5: $109-117$.

- 1936. Cytological studies of the peanut Arachis. 2. Chromosome number, morphology and behavior, and their application to the problem of the origin of the cultivated forms. Cytologia 7: 396-423.

Krapovickas, A. and Gregory, W. C. 1994. Taxonomia del género Arachis (Leguminosae). Bonplandia 8: 1-186.

Peñaloza, A. P. S. 1995. Caracterização dos componentes biológicos da produção de sementes de Arachis pintoi (Leguminosae). MSc Thesis. Universidade de Brasília, Brasilia, Brazil.

Silvarolla, M. B. and Aguiar-Perecin, M. L. R. 1994. Evaluation of chromosome number stability in two sugarcane varieties. Brazilian J. Genet. 17: 237-242.

Simpson, C. E. and Starr, J. L. 2001. Registration of 'Coan’ peanut. Crop Science 41: 918.

Singh, A. K., Stalker, H. T. and Moss, J. P. 1991. Cytogenetics and Use of Alien Genetic Variation in Groundnut Improvement. In: Tsuchiya, T. and Gupta, P. K. (eds.). Chromosome Engineering in Plants: Genetics, Breeding, Evolution, Part B, Elsevier Science Publishers B.V., Amsterdam. pp. 65-77.

—, Subrahmanyam, P. and Gurtu, S. 1996. Variation in a wild groundnut species, Arachis duranensis Krapov. \& W. C. Gregory. Genetic Resources and Crop Evolution 43: 135-142.

Stalker, H. T. 1989. Utilizing Wild Species for Crop Improvement. In: Stalker, H. T. and Chapman, C. (eds.). IBPGR Training Courses: Lecture Series. 2. Scientific Management of Germplasm: Characterization, Evaluation and Enhancement. International Board for Plant Genetic Resources, Rome. pp. 139-154.

— and Dalmacio, R. D. 1981. Chromosome of Arachis species, section Arachis. J. Heredity 72: 403-408.

-, Dhesi, J. S. and Parry, D. C. 1991. An analysis of the B genome species Arachis batizocoi (Fabaceae). Plant Systematic Evolution 174: 159-169.

— and Moss, J. P. 1987. Speciation, citogenetics and utilization of Arachis species. Advances in Agronomy 41: 1-40.

Starr, J. L., Schuster, G. L. and Simpson, C. E. 1990. Characterization of the resistence to Meloidogyne arenaria in an interspecific Arachis spp. hybrid. Peanut Science 17: 106-108.

Tallury, S. P. and Copeland, S. C. 2002. Nondestructive determination of ploidy levels in peanut interspecific hybrids. Proceedings of the American Peanut Research and Education Society, Inc. 34: 117. 